\title{
ANALISA FAKTOR-FAKTOR YANG MEMPENGARUHI STRES DAN MOTIVASI BELAJAR MAHASISWA
}

\author{
Fajar Rinawati ${ }^{1}$, Sucipto ${ }^{1}$ \\ ${ }^{1}$ Departemen Jiwa, Akper Dharma Husada Kediri \\ umminaufal2808@gmail.com
}

\begin{abstract}
ABSTRAK
Mahasiswa keperawatan adalah calon perawat yang harus memiliki kemampuan, baik pengetahuan, sikap dan keterampilan yang baik. Kemampuan mahasiswa ini dapat dipengaruhi oleh stres dan motivasi dalam proses pembelajaran. Berdasarkan hal tersebut, peneliti ingin melihat faktor apa saja yang berpengaruh terhadap stres dan motivasi belajar mahasiswa. Penelitian ini merupakan penelitian kuantitatif dengan desain penelitian deskriptif analisis yang menganalisa faktor-faktor yang mempengaruhi stres dan motivasi belajar mahasiswa. Analisa data menggunakan uji statistik dengan regresi linier. Hasil penelitian menunjukkan beberapa hal, yaitu (1) jenis kelamin, tempat tinggal, penghasilan orang tua, pekerjaan orang tua dan urutan anak, semuanya tidak berpengaruh secara signifikan terhadap stres, (2) jenis kelamin, tempat tinggal, penghasilan orang tua, pekerjaan orang tua dan urutan anak tidak berpengaruh secara signifikan terhadap motivasi belajar mahasiswa, dan hanya penghasilan orang tua yang berpengaruh secara signifikan terhadap motivasi belajar mahasiswa dengan nilai $p$-value 0.048 ( $p$-value $<0.05$ ). Orang tua merupakan orang yang bertanggung jawab dalam biaya pendidikan anaknya, namun secara tidak langsung, jika mahasiswa tersebut mengalami tunggakan biaya pendidikan, hal ini akan mempengaruhi psikologis anak untuk belajar.
\end{abstract}

Kata kunci: faktor, stres, motivasi, dan mahasiswa

\section{ANALYSIS OF FACTORS AFFECTING STRESS AND STUDENT LEARNING MOTIVATION}

\begin{abstract}
Nursing students are prospective nurses who must have the ability, including good knowledge, attitude and good skills. This student ability can be influenced by stress and motivation in the learning process. Based on this, the researcher wants to see what factors influence student stress and learning motivation. This research is a quantitative research with descriptive analysis research design that analyzes the factors that influence stress and student learning motivation. Data analysis using statistical tests with linear regression. The results showed several things, the first gender, place of residence, parents 'income, parent's work and the order of children, all of which did not significantly influence stress, the second gender, place of residence, parents' income, parent's work and the order of children does not significantly influence student learning motivation, and only parents 'income significantly influences students' learning motivation with a p-value: 0.048 (p-value <0.05). Parents are responsible for their children's education costs, but indirectly, if the student experiences delinquent tuition fees, this will affect the child's psychological learning.
\end{abstract}

Keywords: factors, stress, motivation, and students

\section{PENDAHULUAN}

Mahasiswa merupakan pemuda yang diharapkan mampu menjadi generasi penerus bangsa. Mahasiswa keperawatan adalah mahasiswa yang kedepan diharapkan mampu menjadi perawat profesional. Untuk menjadi perawat profesional, diperlukan kemampuan yang baik, sejak mulai kuliah. Kemampuan ini terdiri dari kemampuan secara kognitif, afektif maupun psikomotor (Ali \& Asrori, 2010). Kemampuan ini diperoleh dari hasil pembelajaran. Banyak hal yang mempengaruhi proses pembelajaran, antara lain adanya stres dan motivasi mahasiswa. Penelitian Riyani (2015) tentang faktor-faktor yang mempengaruhi motivasi belajar, dengan 77 responden didapatkan bahwa hal yang mempengaruhi motivasi ada 4 faktor, yaitu (1) 
proses belajar mengajar, metode, sumber dan mahasiswa; (2) bahan ajar, alat, motivasi dan evaluasi; (3) interaksi mahasiswa dengan materi, lingkungan dan kesehatan; dan (4) tujuan dan bakat.

Stres merupakan hal yang diperlukan dalam kehidupan sehari-hari, karena kondisi stres dapat memicu atau menstimulus seseorang untuk melakukan respon atau suatu kegiatan. Namun jika kondisi stres berlebih, ini akan berpengaruh pada kondisi yang dapat memperburuk proses kehidupannya (Stuart, 2013). Stres yang terjadi pada mahasiswa akan berdampak pada proses pembelajaran mahasiswa. Bahkan banyak laporan mengenai percobaan bunuh diri yang terjadi pada mahasiswa, dan ini diperkirakan karena kondisi stres yang dialami oleh mahasiswa, misalnya berita tentang kasus seorang mahasiswa dari Universitas ternama di Indonesia yang mngalami depresi karena nilainya turun dan skripsinya ditolak oleh dosen pembimbing (Saudale, 2016). Baru-baru ini kita juga dihebohkan dengan kejadian bunuh diri seorang mahasiswa di Lampung pada tanggal 22 Februari 2019 (Muslihah, 2019). Dan masih banyak berita lain terkait kasus akibat depresi (kondisi stres) yang terjadi pada mahasiswa.

Selain kondisi stres pada mahasiswa, motivasi juga merupakan salah satu faktor yang dapat mempengaruhi proses pembelajaran. Motivasi adalah suatu hal yang sangat penting yang harus dimiliki seseorang, karena dengan motivasi, akan membuat seseorang melakukan suatu tindakan atau kegiatan untuk mencapai keinginannya. Motivasi juga dapat memacu seseorang untuk tercapainya tujuan yang diharapkan (Bangun, 2012). Penelitian Yusuf (2013) tentang hubungan antara motivasi belajar dengan indeks prestasi belajar mahasiswa PSIK Unsyiah Banda Aceh menunjukkan bahwa ada hubungan yang signifikan antara motivasi belajar dengan indeks prestasi akademik mahasiswa (p-valeu 0.000). Penelitian Sunarsih (2010) tentang hubungan antara motivasi belajar, kemandirian belajar, bimbingan akademik terhadap prestasi belajar mahasiswa, dengan 464 responden, menunjukkan bahwa motivasi belajar, kemandirian belajar, dan bimbingan akademik berpengaruh secara signifikan terhadap prestasi belajar mahasiswa (nilai rho $=0.457$ ) Penelitian Kristini dan Mere (2012) tentang hubungan antara motivasi belajar dan hasil belajar akademik pada mahasiswa juga menunjukkan bahwa ada hubungan yang signifikan. Berdasarkan hal tersebut di atas, maka peneliti tertarik untuk melihat faktor apa saja yang dapat mempengaruhi kondisi stres dan motivasi mahasiswa di Akper Dharma Husada Kediri.

\section{METODE}

Penelitian ini merupakan penelitian kuantitatif dengan desain penelitian deskriptif analisis, yaitu menganalisa faktor-faktor yang mempengaruhi stres dan motivasi belajar mahasiswa Akper Dharma Husada Kediri. Faktor-faktor yang akan diteliti antara lain jenis kelamin, tempat tinggal, penghasilan orang tua, pekerjaan orang tua dan urutan anak. Populasi dalam penelitian ini adalah mahasiswa Akper Dharma Husada Kediri. Jumlah sampel yang sesuai kriteria inklusi dalam penelitian ini sebanyak 39 responden. Instrumen yang digunakan adalah menggunakan skala DASS untuk mengukur stres, sedangkan pengukuran motivasi menggunakan item pernyataan yang telah diuji validitas dan reabilitasnya. Analisa data menggunakan analisa regresi linier.

\section{HASIL}

Tabel 1 menunjukkan bahwa sebagian besar responden (84.6\%) adalah perempuan, dan paling banyak tinggal di kos-kosan (56.4\%), dengan penghasilan orang tua antara Rp. 1.000.000,- sampai dengan Rp. 4.000.000;-. Pekerjaan orang tua mahasiswa sebagian besar adalah PNS (38.5\%) dan mahasiswa ada yang anak pertama (51.3\%) dan selain anak pertama (48.7\%). Tabel 2 menunjukkan bahwa semua faktor (jenis kelamin, tempat tinggal, penghasilan, pekerjaan dan nomor urut anak) tidak mempengaruhi secara signifikan terhadap stres. Tabel 4 menunjukkan bahwa penghasilan mempengaruhi motivasi secara signifikan, sedangkan faktor yang lain (jenis kelamin, tempat tinggal, pekerjaan dan nomer urut anak) tidak mempengaruhi secara signifikan. 
Tabel 1.

Karakteristik Responden ( $\mathrm{n}=39)$

\begin{tabular}{|c|c|c|}
\hline Karakteristik & $\mathrm{f}$ & $\%$ \\
\hline \multicolumn{3}{|l|}{ Jenis kelamin: } \\
\hline Laki-laki & 6 & 15.4 \\
\hline Perempuan & 33 & 84.6 \\
\hline \multicolumn{3}{|l|}{ Tempat tinggal } \\
\hline Kos & 22 & 56.4 \\
\hline Dengan orang tua & 15 & 38.5 \\
\hline Lain-lain & 2 & 5.1 \\
\hline \multicolumn{3}{|l|}{ Penghasilan orang tua } \\
\hline Rp. 1.000.000,- < Rp. 2.000.000,- & 11 & 28.2 \\
\hline Rp. 2.000.000,- < Rp. 3.000.000,- & 11 & 28.2 \\
\hline Rp. 3.000.000,- < Rp. 4.000.000,- & 11 & 28.2 \\
\hline Rp. 4.000.000,- < Rp. 5.000.000,- & 5 & 12.8 \\
\hline$\geq$ Rp. 5.000.000,- & 1 & 2.6 \\
\hline \multicolumn{3}{|l|}{ Pekerjaan orang tua } \\
\hline Wiraswasta & 10 & 25.7 \\
\hline PNS & 15 & 38.5 \\
\hline Swasta & 7 & 17.9 \\
\hline Lain-lain & 7 & 17.9 \\
\hline \multicolumn{3}{|l|}{ Anak ke- } \\
\hline Anak ke-1 & 20 & 51.3 \\
\hline Bukan anak ke-1 & 19 & 48.7 \\
\hline
\end{tabular}

Tabel 2.

Faktor-faktor yang Mempengaruhi Stres pada Mahasiswa $(\mathrm{n}=39)$

\begin{tabular}{lccccc}
\hline \multirow{2}{*}{ Model } & \multicolumn{2}{c}{ Unstandardized Coefficients } & $\begin{array}{c}\text { Standardized } \\
\text { Coefficients }\end{array}$ & $\mathrm{t}$ & \multirow{2}{*}{ Sig. } \\
\cline { 2 - 4 } & $\mathrm{B}$ & Std. Error & Beta & & \\
\hline (Constant) & 75,607 & 11,331 & & 6,672 &, 000 \\
\hline Jenis Kelamin & $-7,638$ & 5,923 &,- 226 & $-1,290$ &, 206 \\
\hline Tinggal & 1,121 & 3,582 &, 055 &, 313 &, 756 \\
\hline Penghasilan &,- 279 & 2,065 &,- 025 &,- 135 &, 893 \\
\hline Pekerjaan & 1,124 & 2,127 &, 096 &, 528 &, 601 \\
\hline Anak &,- 666 & 2,127 &,- 054 &,- 313 &, 756 \\
\hline
\end{tabular}

a. Dependent Variable: Stres

Tabel 3.

Faktor-faktor yang Mempengaruhi Motivasi $(n=39)$

Coefficients $^{\mathrm{a}}$

\begin{tabular}{lrrrrrr}
\hline & \multicolumn{2}{c}{$\begin{array}{l}\text { Unstandardized } \\
\text { Coefficients }\end{array}$} & \multicolumn{2}{c}{$\begin{array}{c}\text { Standardized } \\
\text { Coefficients }\end{array}$} & & \\
\cline { 2 - 5 } Model & \multicolumn{1}{c}{ B } & Std. Error & Beta & & \multicolumn{1}{c}{ Sig. } \\
\hline (Constant) & 147,491 & 18,432 & & & 8,002 &, 000 \\
\hline Jenis Kelamin & 5,104 & 9,635 &, 088 &, 530 &, 600 \\
\hline Tinggal & 7,040 & 5,827 &, 199 & 1,208 &, 236 \\
\hline Penghasilan & $-6,891$ & 3,359 &,- 359 & $-2,052$ &, 048 \\
\hline Pekerjaan & $-3,432$ & 3,461 &,- 169 &,- 992 &, 329 \\
\hline Anak & 5,262 & 3,460 &, 248 & 1,521 &, 138 \\
\hline
\end{tabular}

a. Dependent Variable: Motivasi 


\section{PEMBAHASAN}

Stres merupakan suatu kondisi yang mengharuskan seseorang melakukan suatu tindakan. Semua manusia pasti pernah mengalami kondisi stres, baik laki-laki maupun perempuan (Varcarolis, 2010). Sifat seorang perempuan adalah berperasaan, jadi kondisi stres sangat mungkin dialami oleh lebih banyak mahasiswa perempuan dibandingkan laki-laki karena sifat perempuan yang membawa emosi pada setiap kegiatan. Tempat tinggal yang jauh dari orang tua juga akan memicu mahasiswa mengalami stres, karena mahasiswa tidak bisa mengungkapkan kesulitan-kesulitan yang dihadapi kepada orang tua, terutama menyangkut masalah pengambilan keputusan yang besar, misalnya adanya kebutuhan keuangan yang mendadak, yaitu untuk foto kopi, membuat makalah yang membutuhkan uang untuk print dan kebutuhan lain. Sebagian mahasiswa merupakan anak pertama. Anak pertama mempunyai tanggung jawab lebih pada adik-adiknya, dan mempunyai tanggung jawab untuk memberikan contoh yang baik kepada adikadiknya, sehingga mahasiswa yang merupakan anak pertama akan lebih rentan untuk mengalami stres.

Walaupun jenis kelamin, tempat tinggal, penghasilan, pekerjaan orang tua, dan nomor urut anak dapat mempengaruhi stres, namun berdasarkan uji analisa data faktor ini tidak ada yang secara signifikan mempengaruhi stres. Institusi Akper Dharma Husada merupakan institusi swasta, dimana tuntutannya mungkin lebih rendah daripada institusi negeri, sehingga belum ada faktor yang secara signifikan terbukti dapat mempengaruhi stres mahasiswa. Penelitian Sutjiato (2015) di Fakultas Kedokteran Universitas Sam Ratulangi Manado tentang hubungan faktor internal dan eksternal dengan tingkat stres mahasiswa menunjukkan bahwa jenis kelamin, pengaruh teman sebaya, pengaruh orang tua dan pengaruh dosen berpengaruh terhadap stres. Penelitian Sudarya, dkk (2014) tentang analisis faktor-faktor yang mempengaruhi stres pada mahasiswa, dengan 39 responden, menunjukkan bahwa ada dua faktor yang mempengaruhi stres mahasiswa, yaitu: (1) faktor lingkungan internal yang terdiri dari kondisi fisik, perilaku, minat, kecerdasan emosi, kecerdasan intelektual, dan kecerdasan spiritual, sedangkan faktor kedua (2) faktor lingkungan eksternal yang terdiri dari tugas, lingkungan sosial, dan fisik. Meskipun penelitian lain menunjukkan ada hubungan, namun kondisi tiap institusi bisa saja tidak sama, sehingga kondisi yang tejadi juga berbeda.

Motivasi merupakan hal yang diperlukan untuk meningkatkan hasil belajar mahasiswa (Videback, 2011). Berdasarkan hasil penelitian yang telah dilakukan, hanya penghasilan orang tua yang berpengaruh secara signifikan terhadap motivasi belajar mahasiswa. Akper Dharma Husada Kediri merupakan institusi swasta, dimana institusi swasta biasanya pemasukan hampir $90 \%$ berasal dari mahasiswa, sehingga rata-rata biaya pendidikan jauh lebih mahal dibandingkan dengan institusi negeri/pemerintah. Memang tugas mahasiswa adalah belajar, namun jika biaya pendidikan belum terbayarkan (terjadi tunggakan), hal ini akan mempengaruhi motivasi belajar mahasiswa. Karena salah satu syarat untuk ujian atau kenaikan tingkat salah satunya adalah lunas biaya pendidikan semester sebelumnya. Penelitian Upoyo (2011) tentang analisa faktor-faktor yang mempengaruhi motivasi mahasiswa, dengan 57 responden, menunjukkan bahwa hal yang mempengaruhi motivasi mahasiswa adalah motivasi dari dalam diri dan lingkungan Rumah Sakit, sedangkan waktu, metode, pembimbing klinik dan pembimbing institusi tidak berpengaruh secara signifikan terhadap motivasi.

\section{SIMPULAN DAN SARAN}

\section{Simpulan}

Sebagian besar responden $(84.6 \%)$ adalah perempuan, dan paling banyak tinggal di koskosan $(56.4 \%)$, dengan penghasilan orang tua antara Rp. 1.000.000,- sampai dengan Rp. 4.000.000;-. Pekerjaan orang tua mahasiswa sebagian besar adalah PNS (38.5\%) dan mahasiswa ada yang anak pertama (51.3\%) dan selain anak pertama (48.7\%). Tidak ada faktor yang mempengaruhi secara signifikan terhadap stres, baik jenis kelamin, tempat tinggal, penghasilan, pekerjaan dan nomor urut anak. Hanya Penghasilan yang mempengaruhi motivasi secara signifikan, sedangkan faktor yang lain (jenis kelamin, tempat tinggal, 
pekerjaan dan nomer urut anak) tidak mempengaruhi secara signifikan.

\section{Saran}

Bagi Institusi Pendidikan diharapkan ada transparansi pembayaran mulai dari awal masuk pendidikan, dan diharapkan ada pemberitahuan jauh-jauh hari sebelum masa pembayaran berakhir.

\section{DAFTAR PUSTAKA}

Ali \& Asrorori. (2010). Psikologi Remaja Perkembangan Peserta Dididk. Jakarta: Bumi Aksara

Bangun, W. (2012). Manajemen Sumber Daya Manusia. Jakarta: Erlangga

Kristini, R. E., \& Mere, F. N. (2012). Hubungan antara motivasi belajar dengan prestasi akademik pada mahasiswa prodi keperawatan S1 Program A angkatan I Stikes Rs. Baptis Kediri. Jurnal Penelitian STIKES Kediri, 3(1), 13-18.

Muslihah, E. (2019). Banyak yang Merekam tetapi Tak Menolong, Ini Fakta Kasus Mahasiswa Bunuh Diri di Lampung. https://regional.kompas.com/read/2019/02 123/15072161/banyak-yang-merekamtetapi-tak-menolong-ini-fakta-kasusmahasiswa-bunuh-diri?page=all.

Kompas.com

Riyani, Y. (2015). Faktor-faktor yang mempengaruhi prestasi belajar mahasiswa (studi pada mahasiswa Jurusan Akuntansi Politeknik Negeri Pontianak).

Saudale, V (2016). Mahasiswa UI Diduga Gantung Diri karena Depresi. https://www.beritasatu.com/megapolitan /367736/mahasiswa-ui-gantung-dirididuga-depresi. Berita Satu.com
Stuart, G.W. (2013). Principles and Practice of Psychiatric Nursing. $10^{\text {th }}$ Ed. Canada: Evolve.

Sudarya, I. W., Bagia, I. W., Si, M., \& Suwendra, I. W. (2014). Analisis Faktor-Faktor yang Mempengaruhi Stres pada Mahasiswa dalam Penyusunan Skripsi Jurusan Manajemen Undiksha Angkatan 2009. Jurnal Jurusan Manajemen, 2(1).

Sunarsih, T. (2010). Hubungan antara motivasi belajar, kemandirian belajar dan bimbingan akademik terhadap prestasi belajar mahasiswa di Stikes A. Yani Yogyakarta (Doctoral dissertation, Universitas Sebelas Maret).

Sutjiato, M. (2015). Hubungan faktor internal dan eksternal dengan tingkat stress pada mahasiswa Fakultas Kedokteran Universitas Sam Ratulangi Manado. JIKMU, 5(1).

Upoyo, A. S., \& Sumarwati, M. (2011). Analisis Faktor-Faktor yang Mempengaruhi Motivasi Mahasiswa Profesi Ners Jurusan Keperawatan Unsoed Purwokerto. Jurnal Keperawatan Soedirman, 6(2), 81-87.

Varcarolis, E.M. \& Halter, M.J. (2010). Psychiatric Mental Health Nursing, A Clinical Approach. $6^{\text {th }}$ Ed. Canada: Elsevier.

Videback, S.L. (2011). Psychiatric-Mental Health Nursing. $4^{\text {th }}$ Ed. China: Wolters Kluwer.

Yusuf, M. (2013). hubungan motivasi belajar dengan indeks prestasi akademik mahasiswa program studi ilmu keperawatan fakultas kedokteran unsyiah banda aceh. Idea Nursing Journal, 4(3). 
Jurnal Keperawatan Jiwa Volume 7 No 1 Hal 95 - 100, Mei 2019

FIKKes Universitas Muhammadiyah Semarang bekerjasama dengan PPNI Jawa Tengah 